Original Research Paper

\title{
Characteristics of Feather Protein Concentrates Hydrolyzed Using Bacillus subtilis FNCC 0059
}

\author{
${ }^{1}$ Muhammad Irfan Said, ${ }^{2}$ Effendi Abustam, ${ }^{3}$ Farida Nur Yuliati and ${ }^{4}$ Muhammad Zain Mide \\ ${ }^{1}$ Lab. of Animal By-Products Processing Technology, \\ ${ }^{2}$ Lab. of Meat dan Egg Processing Technology, \\ ${ }^{3}$ Lab. of Microbiology and Animal Health, \\ ${ }^{4}$ Lab. of Animal Feed Industry, \\ ${ }^{1,2,3,4}$ Faculty of Animal Science, Hasanuddin University, \\ Jl.Perintis Kemerdekaan Km.10, Makassar, 90245, Indonesia
}

Article history

Received: 25-11-2017

Revised: 23-12-2017

Accepted: 04-01-2018

Corresponding Author: Muhammad Irfan Said Lab. of Animal By-Products

Processing Technology, Faculty of Animal Science, Hasanuddin University, Jl.Perintis Kemerdekaan Km.10, Makassar, 90245, Indonesia

Tell: $+62-411-587217$

Fax: +62-411-90245

Email: irfan.said@unhas.ac.id

\begin{abstract}
Fermentation technology is one technology that can be applied in the process of hydrolysis and decomposition of keratin protein in chicken feather waste. The fermentation technology can use microbial bacteria as a decomposer to improve the digestibility of the Feather Waste (FW). The purpose of this study was to evaluate the properties of chicken feather waste and Feather Protein Concentrate (FPC) fermented using Bacillus subtilis FNCC 0059. The properties of the feather-waste as control and FPC were studied specifically related to the dry matter protein digestibility properties performed in-vitro, water content, protein content, fat content, fiber content, NDF levels and amino acid profile. A total of 2 types of samples are compared the properties, namely FPC and FW. Bacterial isolates of Bacillus subtilis FNCC 0059 enriched with nutrient broth and propagated in a mixture of molasses and nutrient broth solution as a fermentation agent. The fermentation process was carried out for 4 weeks in the incubator at $35^{\circ} \mathrm{C}$. The data were processed statistically by using Ttest to compare the properties of FW with FPC fermentation for 4 weeks. The results showed that the properties of In-vitro Protein Digestibility (IvPD), moisture content, fiber content, NDF significantly differed $(p>0.05)$ between FW and FPC, while protein and fat content were not significantly different $(p>0.05)$. The amino acid profile in both samples has similarities.
\end{abstract}

Keywords: Concentrate, Feather Waste, Hydrolysis, Bacteria, Keratin

\section{Introduction}

Chicken is one of the main sources of protein for humans. At present, chicken production worldwide reaches 96 million tons per year. Based on this amount, it is estimated that the average consumption amount reaches $14 \mathrm{~kg} /$ person/year (FAO, 2015). The feather consists of $5-7 \%$ of the chicken's life weight. Based on this, there are about 6 million tons of feather waste produced as the byproducts of the poultry industry (Onifade et al., 1998). Utilization by-product of feather as animal feed material is one of effort to decrease livestock waste production (Said et al., 2016b). This is a challenge that requires a solution.

Poultry slaughterhouse is one of the industries that produce a lot of feather waste (Riffel and Brandelli, 2006; Darah et al., 2013). The feather waste contains a number of keratin proteins that have very low digestibility (Gopinath et al., 2015). Keratin is a biopolymer that structures the feather waste (Martínez-Hernández and Velasco-Santos, 2012; Amieva et al., 2014; Cao et al., 2012). The feather waste contains $80-90$ keratin proteins that are dominated by the amino acid cysteine through disulfide bonds, which cause keratin to be stable from the influence of peptidase hydrolysis such as pepsin, trypsin and papain. This resistance is related to the presence of $\alpha$-keratin and $\beta$-keratin bonds (Brandelli et al., 2015). Keratin is made up of several sulfuric amino acids that make up the disulfide bond (Pruekvimolphan and Grummer, 2011). Hydrolysis process with heat has not been able to improve the digestibility of powdered feather as a feed material (Grazziotin et al., 2006). On the other hand, the production of feather waste from cutting industries requires serious handling. 
One effort to reduce the production of feather waste is to process it into animal feed ingredients. Some livestock industries are seeking alternative sources of abundant protein at a low cost. However, enzymatic hydrolysis technology becomes an option for scientists to develop further (Jayathilakan et al., 2012). Feather waste is one of the alternative sources of protein for livestock, especially monogastric (Hasni et al., 2014; Scholljegerdes et al., 2005) and in plants (Zheljazkov, 2005).

As an alternative, the role of microbes in the enzymatic hydrolysis process needs to be considered. The use of keratinase-producing microbes can increase the availability of amino acids in keratin. Several types of microbes are known to produce keratinase enzymes such as Bacillus spp (Bacillus licheniformis and Bacillus subtilis as well as actinomycetes fungi (Lin et al., 1992; Mazotto et al., 2011; Abdel-Naby et al., 2016). Reddy et al. (2017) has developed Bacillus pumilus GRK bacteria as a keratinase producer with the ability to degrade the protein of $98.3 \%$ this bacterium is developed as bio additive in bio detergent. Among the existing microbes, the Bacillus genus is one of the potential protease producers and has been used in some (Rao et al., 1998, Gupta and Ramnani, 2006). This study will be evaluated related to the effect of long hydrolysis process by microbial fermentation method using bacterium Bacillus subtilis FNCC 0059 on the characteristics of broiler feather protein concentrate.

\section{Materials and Methods}

\section{Research Materials}

This research used raw the material of Feather Waste (FW) from Poultry Slaughtering House (PSH) at Daya village, Makassar city, South Sulawesi, Indonesia. Bacterial isolates of Bacillus subtilis FNCC 0059 (Lab of Biotechnology, Pusat Antar Universitas (PAU), Gadjah Mada University, Yogyakarta; nutrient broth (Oxoid); molasses (Takalar Sugar Factory, Takalar District, South Sulawesi); 20\% (w/v) NaOH 1M (Sigma); aquadest (Lab of Animal Feed Chemistry, Faculty of Animal Science, Hasanuddin University). Equipment used: Near InfraRed (NIR) (NIRFlex Solids); incubator (Memmert); autoclave (Olla Autoclave Electrica All American 75X); oven (Memmert); grinder (Sanyo); analytical scales (Sartorius TE 214S); beaker glass (Pyrex); erlemenyer (Pyrex), measuring cup (Pyrex) and volume pipette (Pyrex).

\section{Research Method}

\section{The Process of Supplying Raw Materials}

The raw material of broiler FW was obtained from the process of removing the feather (defeathering) of PSH. A total of $1000 \mathrm{~g}$ of fresh FW was prepared for all treatments. The FW was washed thoroughly, then dried with the oven at $60{ }^{\circ} \mathrm{C}$ for $15 \mathrm{~h}$. The $\mathrm{FW}$ was immersed in $20 \%(\mathrm{v} / \mathrm{v}) \mathrm{NaOH} 1 \mathrm{M}$ solution for $4 \mathrm{~h}$.

Subsequently, the sample was steamed in the autoclave at a pressure of $21 \mathrm{Psi}(1.24 \mathrm{~atm})$ for $10 \mathrm{~h}$. The feather sample was dried in an oven at $60{ }^{\circ} \mathrm{C}$ for $24 \mathrm{~h}$. The dried samples are then milled and put into a sample bottle. The dried samples are then milled and put into a sample bottle.

\section{Inoculan Supply Process on Fermentation Media}

Bacillus subtilis FNCC 0059 was inoculated in the $100 \mathrm{ml}$ nutrient broth medium. The culture was incubated at $37{ }^{\circ} \mathrm{C}$ for $24 \mathrm{~h}$. The fermentation medium was prepared with a formula of $1000 \mathrm{~mL}$ of aquadest $+100 \mathrm{~mL}$ molasses $+100 \mathrm{~mL}$ nutrient broth. The fermentation medium was further sterilized in an autoclave at $121{ }^{\circ} \mathrm{C}$ for $15 \mathrm{~min}$. A total of $2 \%$ of bacterial culture of Bacillus subtilis FNCC 0059 were inoculated into fermentation medium. The fermentation medium was then incubated at $37^{\circ} \mathrm{C}$ for $18 \mathrm{~h}$.

\section{Fermentation Process Using Bacillus subtilis FNCC 0059}

A total of $250 \mathrm{~g}$ of each FPC and FW were sterilized by autoclaving at $121{ }^{\circ} \mathrm{C}$ for $15 \mathrm{~min}$. The sample was then into a sterile glass container. Bacillus subtilis FNCC 0059 is then mixed with a homogeneous feather sample. A total of $50 \mathrm{~g}$ of each sample was inserted into a sterile sample bottle, then closed and incubated at $35{ }^{\circ} \mathrm{C}$ for $1,2,3$ and 4 weeks. The sample test was conducted at the $1^{\text {st }}, 2^{\text {nd }}, 3^{\text {rd }}$ and $4^{\text {th }}$ weeks.

\section{Parameter of the Study}

The research parameters included: In-vitro Protein Digestibility (IvPD), moisture content, protein content, fat content, ash content, crude fiber content and amino acid profile.

\section{Research Design and Data Analysis}

The experiment was conducted in a laboratory experiment by comparing the properties of FPC with FW. The statistical test uses the T-test to compare the properties of 2 types of products at the $5 \%$ level (Steel and Torrie, 1991).

\section{Analysis Methods \\ In-Vitro Protein Digestibility (IvPD)(\%)}

AOAC International (1997; Swaisgood and Catignani, 1991). This method imitates the digestive function of livestock (Moyano et al., 2015). In this research, the determination of IvPD using pepsin method. A total of 1 $\mathrm{g}$ of sample was inserted into the porcelain cup to determine the dry matter and the organic material. Each cup was added $25 \mathrm{~mL}$ of pepsin acid solution, incubated 
for $72 \mathrm{~h}$ at $50{ }^{\circ} \mathrm{C}$. The shaking process was performed during the incubation process. The contents of the cup were filtered with cruisable no 2 . Cruisable was dried overnight at $103{ }^{\circ} \mathrm{C}$ and it was ignored at $520^{\circ} \mathrm{C}$ for $3 \mathrm{~h}$. The IvPD was calculated by the equation $=$ Dry Matter Digested $(\mathrm{DMD})(\%)=\mathrm{B}-\mathrm{C} / \mathrm{A} \times 100 \%$; IvPD $(\%)=$ $100 \%$ - DMD. Where, $\mathrm{A}=$ sample weight, $\mathrm{B}=$ cruisable weight after oven and $\mathrm{C}=$ empty cruisable weight.

\section{Proximate Analysis}

The values of water content $(\%)$, protein content $(\%)$, fat content $(\%)$, fiber content $(\%)$ and NDF content $(\%)$ were determined by proximate analysis method (AOAC International, 1997) using Near Infra Red (NIR) (NIRFlex Solids).

\section{Amino Acid Profile}

The percentage of amino acids (\%) was determined directly using the Near Infra-Red (NIR) (NIRFlex Solids) approach.

\section{Results and Discussion}

\section{In-Vitro Protein Digestibility (IvPD)}

Changes in the IvPD levels of FPC and FW during the fermentation process using Bacillus subtilis FNCC 0059 were presented in Fig. 1.

Based on the result of T-test the data in Fig. 1 shows that the application of fermentation process using Bacillus subtilis FNCC 0059 bacteria on FW and FPC showed the significant difference $(p<0,05)$. These results were related to the IvPD. The level of protein digestibility in FPC is higher than the FW. In the FPC, during the fermentation process showed a trend of increasing protein digestibility of dry matter until the $3^{\text {rd }}$ week, but entering the $4^{\text {th }}$ week of the digestibility level decreased. This happens because the enzyme from the bacterium Bacillus subtilis FNCC 0059 may work only until the $3^{\text {rd }}$ week. The IvPD value during fermentation process was in the range of $62.73-68.91 \%$. These results are similar to those obtained by other researchers using enzymes in the feather hydrolysis process (68-70\%) (Eaksuree et al., 2016) and 79.31\% using B.licheniformis S6 (Gang et al., 2013).

\section{Water Content}

Water content is an important factor in a fermentation process. The water content in feed ingredients affects the quality of feed. Water content was also related to the shelf-life that directly affects the distribution process. Changes in the water content of FPC and FW during the fermentation process by Bacillus subtilis FNCC 0059 were presented in Fig. 2.

Based on Fig. 2, it can be seen that during the fermentation process there was a decrease in water content, both on FPC and FW. Each fermented material had an increase in water content in the $2^{\text {nd }}$ week but subsequently decreased in the $3^{\text {rd }}$ week. The value of water content varies between treatments with an average value of $0.90-3.42 \%$ for FPC higher than FW (3.01$5.90 \%$ ). The result of the statistical test (T-test) showed that the application of fermentation process on the feather waste was significantly different $(p<0.05)$ on the water content. According to Thiex and Richardson (2003), the value of water content is important in a feed industry. Water content was determined by the amount of water evaporation and loss of weight during the drying process. The value obtained was lower than Tesfaye et al. (2017) with the water content of $12.33 \%$.

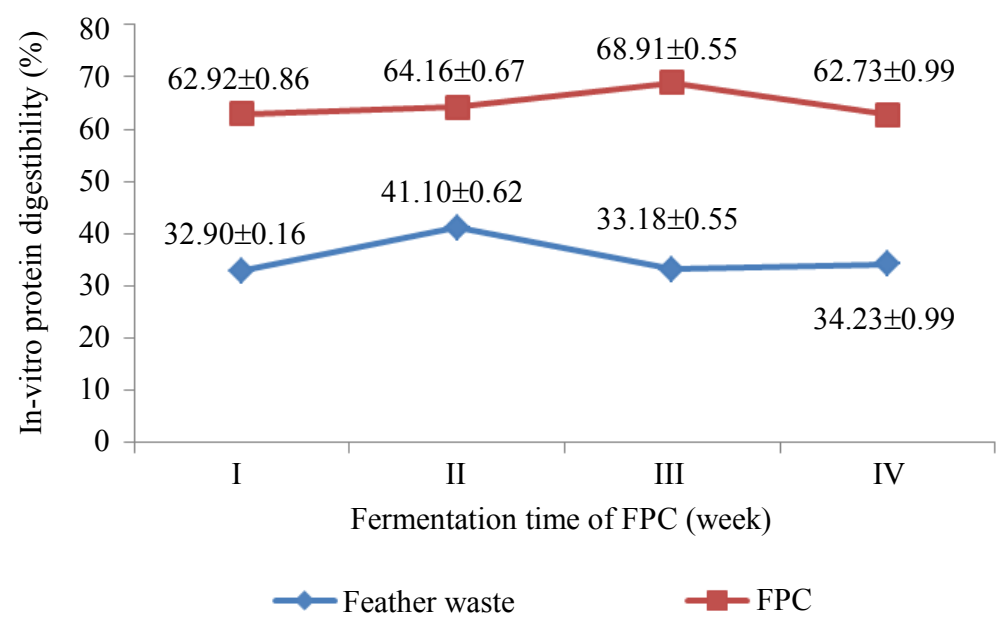

Fig. 1: Comparison of the IvPD (\%) of FPC with FW during the fermentation process using Bacillus subtilis FNCC 0059 bacteria; FPC $=$ Feather Protein Concentrate; FW = Feather Waste; the statistical test showed a significant difference $(p<0.05)$ based on the T-test 


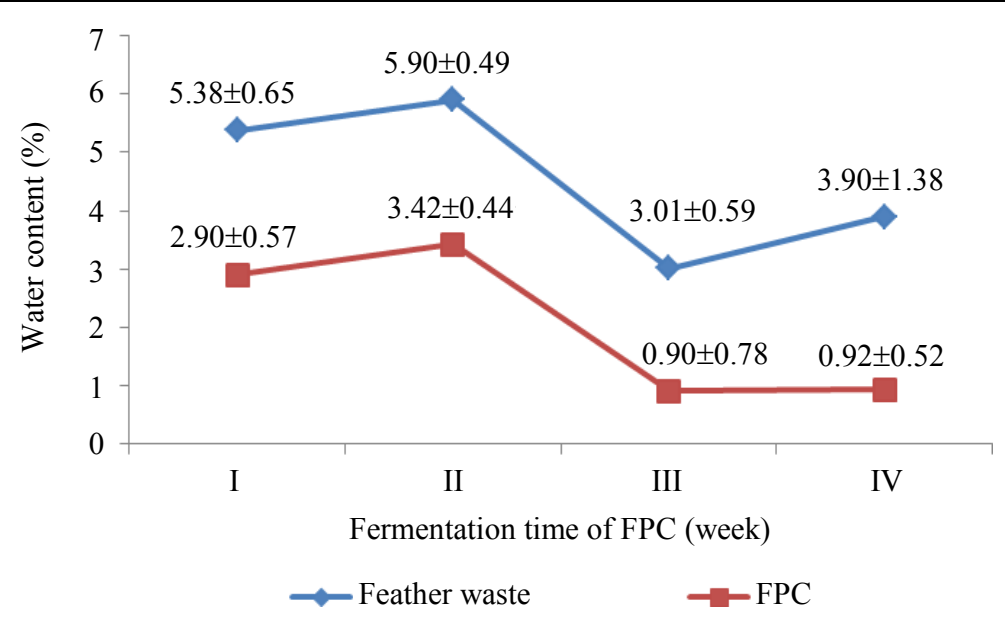

Fig. 2: Comparison of the water content (\%) of FPC with FW during the fermentation process using Bacillus subtilis FNCC 0059 bacteria; FPC $=$ Feather Protein Concentrate; FW = Feather Waste; the statistical test showed a significant difference $(p<0.05)$ on the T-test

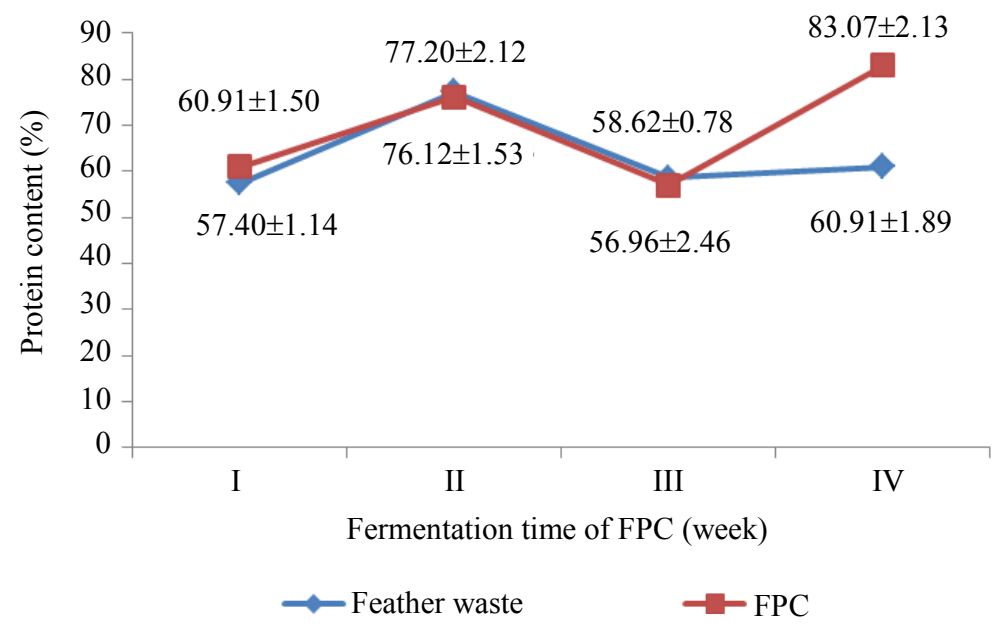

Fig. 3: Comparison of the protein content (\%) of FPC with FW during the fermentation process using Bacillus subtilis FNCC 0059 bacteria; FPC $=$ Feather Protein Concentrate; FW = Feather Waste; the statistical test showed no-significant difference $(p>0.05)$ based on the T-test

\section{Protein Content}

Feather waste from the livestock has potential as a source of protein in animal feed (Van-Heugten and Van-Kempen, 2002). The FW contains amino acid cysteine. Feather meal is an excellent source of amino acids with a predominant supply of cystine from the composition (Klemesrud et al., 2000). The comparison of the protein content of FPC with FW during the fermentation process using Bacillus subtilis FNCC 0059 was presented in Fig. 3.

The process of fermentation using Bacillus subtilis FNCC 0059 bacteria will activate the action of protease enzymes. The result of statistical test (T-test) data in Fig. 3 shows that there is no significant difference $(p>0.05)$ of FPC protein content with FW during the fermentation process. This is because each enzyme has a specific work activity. The enzyme will work according to the existing substrate. If the substrate using the same, then the enzyme will tend to produce the same product.

The activity of the enzyme can cause protein denaturation process. The denaturation process can occur because there is the replacement process of ions in the protein structure of the feather. The addition of fluoride added with hydrogen peroxide $(5 \% \mathrm{w} / \mathrm{w})$ increased the degradability of the in situ protein, however, did not alter the dry matter intake, average weight, feed efficiency and improved characteristic of the carcass cattle (Loest et al., 2002). The value of the protein content of FPC is not different from protein content of feather meal derived from the skin of Bali cattle (85.20-87.67\%) (Said et al., 2016a) and research result by Gang et al. (2013) (79.50\%). The 
results obtained are also not different from the results of research by Tesfaye et al. (2017) (82.36\%).

\section{Fat Content}

Fat is one source of energy after carbohydrates. Fat has the highest energy source compared to carbohydrates and proteins. Fat was used to meet the source of metabolic energy. Comparison of fat content between FW and FPC through the fermentation process using Bacillus subtilis FNCC 0059 was presented in Fig. 4.

Based on the results of statistical tests (T-test) data in Fig. 4 shows that the application of Bacillus subtilis FNCC 0059 bacteria in the fermentation process showed no- significant difference $(p>0.05)$, especially in the fat content between FW and FPC. Fat content in FPC varies from 5.53-6.05\%. The average fat content of FPC products was higher than the fat content of chicken feather in the study of Zerdani et al. (2004) of $1.2 \%$. The fat content of FPC obtained was also higher than Tesfaye et al. (2017) with a value of $0.83 \%$.

\section{Fiber Content}

Fiber is essentially a feed material that can not be hydrolyzed by digestive enzymes. Fiber plays a role in binding water, cellulose and pectin. Comparison of fiber content of FPC with FW was presented in Fig. 5.

The result of the statistical test (T-test) of the data in Fig. 5 shows that the application of Bacillus subtilis FNCC 0059 bacteria in the fermentation process of FPC and FW was significantly different $(p<0.05)$ on the fiber content. During the fermentation process, there was a significant increase in fiber content in the $3^{\text {rd }}$ week. The mean value of FPC fiber content varied with a range of $3.46-5.72 \%$ higher than fiber in FW $(0.23-0.73 \%)$. The fiber content of FPC is not much different from the result of Tesfaye et al. (2017) that is $2.15 \%$.

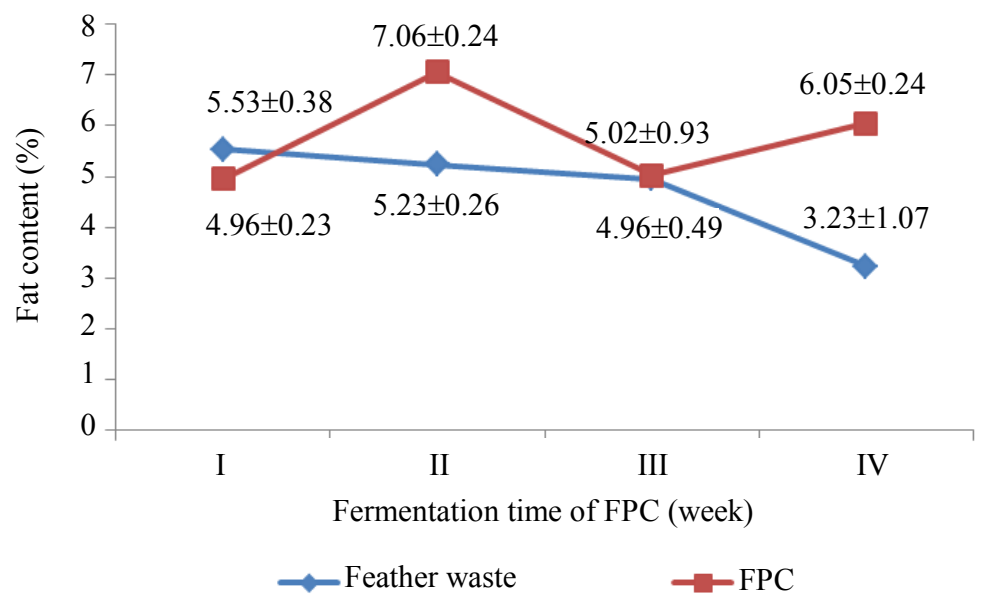

Fig. 4: Comparison of the fat content (\%) of FPC with FW during the fermentation process using Bacillus subtilis FNCC 0059 bacteria; FPC $=$ Feather Protein Concentrate; FW = Feather Waste; the statistical test showed no-significant difference $(p>0.05)$ based on the T-test

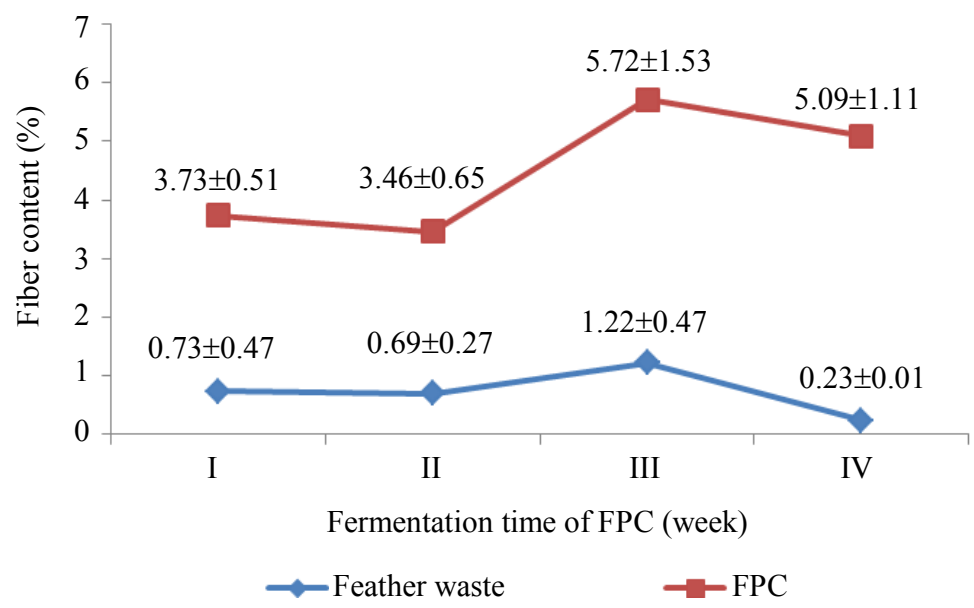

Fig. 5: Comparison of the fiber content (\%) of FPC with FW during the fermentation process using Bacillus subtilis FNCC 0059 bacteria; FPC $=$ Feather Protein Concentrate; FW = Feather Waste; the statistical test showed a significant difference $(p<0.05)$ based on 


\section{NDF Content}

Neutral Detergent Fiber (NDF) describes all the structural hydrate components in plant cell walls that include cellulose, cellulose and lignin (NRC, 2001). $\mathrm{ADF}$ and NDF were fibers that the difficult to digest but are directly involved in the nutrient digestion process (Liu et al., 2014). The comparison of NDF values between FPC with FW was presented in Fig 6 .

Based on the results of statistical analysis (T-test) (Fig. 6) showed that the level of NDF of feather waste was significantly different $(p<0.05)$ with FPC during the fermentation process using Bacillus subtilis FNCC 0059. During the fermentation process increased NDF value especially in the $3^{\text {rd }}$ week after entering the fermentation period in the $4^{\text {th }}$ week.

\section{Amino Acid Profile}

Amino acids are a part of proteins. The balance of amino acids in the feed is in line with Liebig's minimum law. The law states that the deficiency of one of the essential amino acids in the diet will result in the inhibition of the use of other amino acids, although the amino acid is readily available in the diet. Comparison of amino acid profiles in FPC with FW was shown in Fig. 7

According to Fig. 7, the amino acid profiles of both samples are similar. The dominant proportion of amino acids were the glutamic acid, leucine and proline amino acids. The similarity of the amino acid profile gives an indication that there is little change in the amino acid composition occurring during the fermentation process.

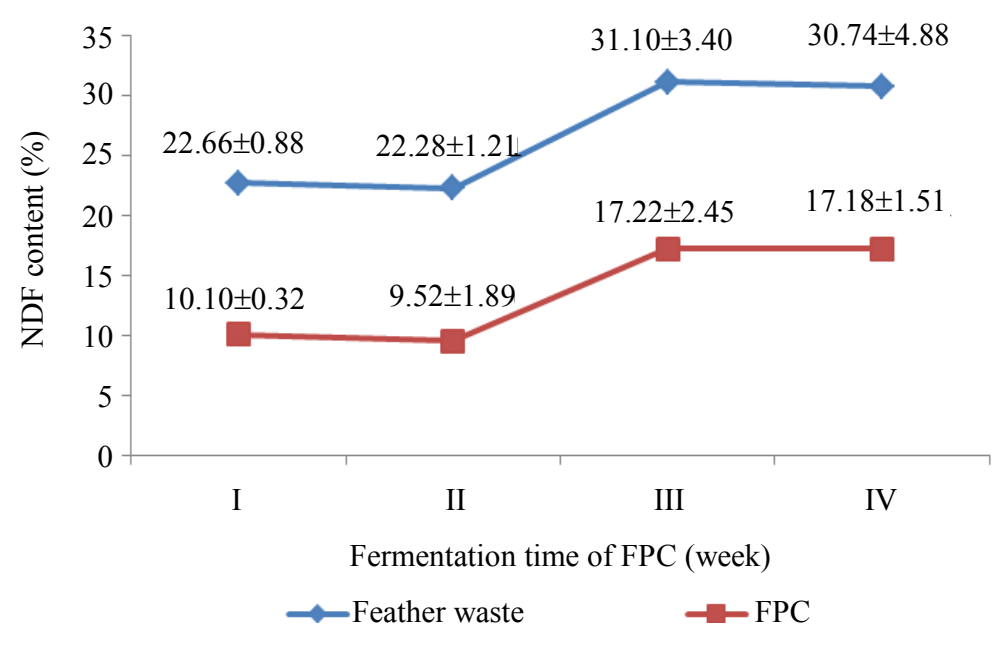

Fig. 6: Comparison of the NDF content (\%) of FPC with FW during the fermentation process using Bacillus subtilis FNCC 0059 bacteria; $\mathrm{FPC}=$ Feather Protein Concentrate; FW = Feather Waste; the statistical test showed a significant difference $(p<0.05)$ based on

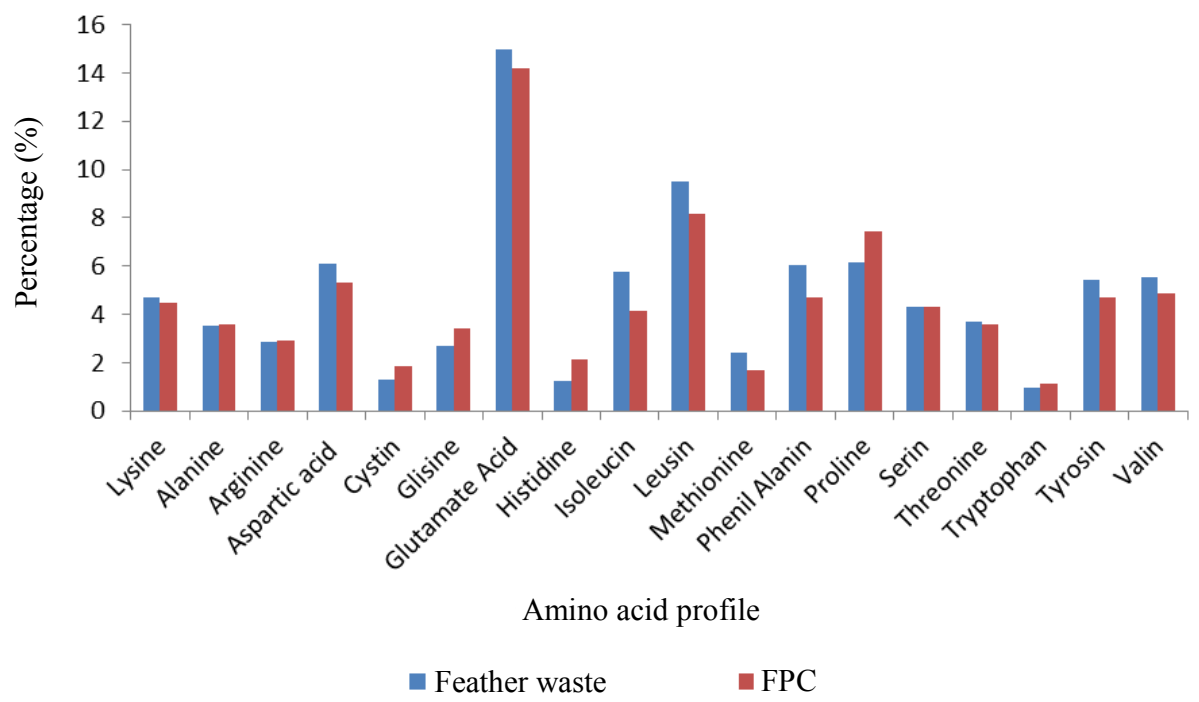

Fig. 7: Comparison of the profile amino acid (\%) of FPC with FW using Bacillus subtilis FNCC 0059 bacteria; FPC $=$ Feather Protein Concentrate; FW = Feather Waste 
The FPC amino acid profile was similar to the amino acid chicken flour produced by Gang et al. (2013) with dominant amino acids are glutamic acid, proline and serine. The hydrolysis process using enzymes is an alternative process that needs to be considered. The application of hydro-thermal processes can lead to the loss of amino acids with low digestibility. Thus the hydrolysis process using enzymes from microbes has enormous benefits (Brandelli, 2008; Mabrouk, 2008).

\section{Conclusion}

The application of hydrolysis process using Bacillus subtilis FNCC 0059 during the fermentation process improves the properties of FPC. The fermentation process using Bacillus subtilis FNCC 0059 improves In-vitro Protein Digestibility (IvPD), lowers water content, increases fiber and NDF levels and does not affect protein levels and amino acid composition. The fermentation process on the FPC using Bacillus subtilis FNCC 0059 bacteria was recommended until the $3^{\text {rd }}$ week to produce FPC products with the better properties.

\section{Acknowlegment}

The authors would like to thank the Ministry of Research, Technology and Higher Education, Republic of Indonesia, Rector of Hasanuddin University, Institute for Research and Community Service (IRCS) of Hasanuddin University for research funding support through Hibah Insinas Riset Pratama Individu Program.

\section{Author Contribution}

Muhammad Irfan Said: Participated in all experiments, coordinated the data-analysis and contributed to the writing of the manuscript.

Effendi Abustam: Designed the experiments and assisted in data analyzed and contributed to the writing of the manuscript.

Farida Nur Yuliati: Collected the field data performed the statistical analysis.

Muhammad Zain Mide: Collected the field data and participated in all experiments.

\section{Ethics}

This article is original and has not been published or presented elsewhere. All the authors have approved the manuscript and agree with submission to this journal. There is no conflict interest to be declared.

\section{References}

Abdel-Naby, M.A., M.H. Ibrahim and H.A. El-Refai, 2016. Catalytic, kinetic and thermodynamic properties of bacillus pumilus FH9 keratinase conjugated with activated pectin. Int. J. Bio. Macromol., 85: 238-245. DOI: 10.1016/j.ijbiomac.2015.12.078

Amieva, E.J.C., C. Velasco-Santos, A.L. MartínezHernández, J.L. Rivera-Armenta and A.M. Mendoza-Martínez et al., 2014. Composites from chicken feathers quill and recycled polypropylene. J. Comp. Mater., 49: 275-283. DOI: $10.1177 / 0021998313518359$

AOAC International, 1997. Official Methods of Analysis of AOAC International. 18th Edn., AOAC International, Gaith-Ersburg, MD.

Brandelli, A., 2008. Bacterial keratinases: Useful enzymes for bioprocessing agroindustrial wastes and beyond. Food Bioproc. Technol., 1: 105-116 DOI: $10.1007 / \mathrm{s} 11947-007-0025-\mathrm{y}$

Brandelli, A., L. Sala and S.J. Kalil, 2015. Microbial enzymes for bioconversion of poultry waste into added-value products. Food Res. Int., 73: 3-12. DOI: 10.1016/j.foodres.2015.01.015

Cao, Z.J., D. Lu, L.S. Luo, Y.X. Deng and Y.G. Bian et al., 2012. Composition analysis and application of degradation products of whole feathers through a large scale of fermentation. Environ. Sci. Pollut. Res. Int., 19: 2690-2696. DOI: 10.1007/s11356-012-0763-x

Darah, I., A. Nur-diyana, S. Nurul-husna, K. Jain and S. Lim, 2013. Microsporum fulvum IBRL SD3: As novel isolate for chicken feathers degradation. Applied Biochem. Biotechnol., 171: 1900-1910. DOI: $10.1007 / \mathrm{s} 12010-013-0496-4$

Eaksuree, W., A. Prachayakitti, T. Upathanpreecha, R. Taharnklaew and S. Nitisinprasert et al., 2016. In vitro and in vivo evaluation of protein quality of enzymatic treated feather meals. SpringerPlus, 5: 1-6. DOI: 10.1186/s40064-016-2626-2

FAO, 2015. Agribusiness Handbook: Poultry, Meat Eggs. In: Food and Agriculture. Organization of the United Nations.

Gang, G., C. Jie, W. Jun-gao, H. Qiu-Xia, L. Ke-chun, 2013. A two-step biotechnological process for improving nutrition value of feather meal by Bacillus licheniformis S6. J. Northeast Agric. Univ. (English Edition), 20: 71-77. DOI: 10.1016/S1006-8104(14)60011-8

Gopinath, S.C.B., P. Anbu, T. Lakshmipriya, T.H. Tang and Y. Chen et al., 2015. Biotechnological aspects and perspective of microbial keratinase production. BioMed. Res. Int., (Rev. Article), 2015: 1-10. DOI: $10.1155 / 2015 / 140726$ 
Grazziotin, A., F.A. Pimentel, E.V. de Jong and A. Brandelli, 2006. Nutritional improvement of feather protein by treatment with microbial keratinase. Animal Feed Sci. Technol., 126: 135-144. DOI: 10.1016/j.anifeedsci.2005.06.002

Gupta, R. and P. Ramnani, 2006. Microbial keratinases and their prospective applications: An overview. Applied Microbiol. Biotechnol., 70: 21-33. DOI: $10.4061 / 2011 / 487093$

Hasni, M.S., H.A. Sahito, M.A. Memon, M.I. Sanjrani and M.A. Gopang et al., 2014. Effect of feeding various levels of feather meal as a replacement of fish meal on the growth of broiler. Int. J. Agric. Innovat. Res., 3: 505-511.

Jayathilakan, K., K. Sultana, K. Radhakrishna and A.S. Bawa, 2012. Utilization of byproducts and waste materials from meat, poultry and fish processing industries: A review. J. Food Sci. Technol., 49: 278-293. DOI: 10.1007/s13197-011-0290-7

Klemesrud, M.J., T.J. Klopfenstein and A.J. Lewis, 2000. Evaluation of feather meal as a source of sulfur amino acids for growing steers. J. Anim. Sci., 78: 207-215.

Lin, X., C. Lee, E.S. Casale and J.H. Shih, 1992. Purification and characterization of a keratinase from a feather-degrading Bacillus licheniformis strain. Applied Environ. Microbiol., 58: 3271-3275.

Liu, J., C. Bai, L. Yan, S. Chen and Y. Zhang et al., 2014. Nutritional value evaluation of saccharum spontaneum L. germplasm resources. Agric. Sci. Technol., 15: 1981-1986.

Loest, C.A., E.C. Titgemeyer, J.S. Drouillard, C.M. Coetzer and R.D. Hunter et al., 2002. Supplemental betaine and peroxide-treated feather meal for finishing cattle. J. Anim. Sci., 80: 2234-2240. DOI: $10.2527 / 2002.8092234 x$

Mabrouk, M.E.M., 2008. Feather degradation by a new keratinolytic Streptomyces sp. MS-2. World J. Microbol. Biotechnol., 24: 2331-2338.

DOI: $10.1007 / \mathrm{s} 11274-008-9748-9$

Martínez-Hernández, A.L. and C. Velasco-Santos, 2012. Keratin Fibers From Chicken Feathers: Structure and Advances in Polymer Composites. In: Keratin: Structure, Properties and Applications, Dullaart, R. and J. Mousquès (Eds.), Nova Science Publishers, ISBN-10: 978-1-62100-336-6, pp: 149-211.

Mazotto, A.M., A.C. de Melo, A. Macrae, A.S. Rosado and R. Peixoto et al., 2011. Biodegradation of feather waste by extracellular keratinases and gelatinases from Bacillus spp. World J. Microbol. Biotechnol., 27: 1355-1365. DOI: $10.1007 / \mathrm{s} 11274-010-0586-1$

Moyano, F.J., M.A. Saénz de Rodrigáñez, M. Díaz and A.G.J. Tacon, 2015. Application of in vitro digestibility methods in aquaculture: Constraints and perspectives. Rev. Aquacult., 7: 223-242.

DOI: 10.1111/raq.12065
NRC, 2001. Nutrient Requirements of Dairy Cattle. 7th Edn., National Research Council, National Academy Press, Washington, D.C., ISBN-10: 0309515211, pp: 380.

Onifade, A.A., N.A. Al-Sane, A. Al- Musallam and S. AlZarban, 1998. A review potentials for biotechnological applications of keratin-degrading microorganisms and their enzymes for nutritional improvement of feathers and other keratins as livestock feed resource. Bioresource Technol., 66: 1-11. DOI: 10.1016/S0960-8524(98)00033-9

Pruekvimolphan, S. and R.R. Grummer, 2011. Lactation responses to sulfur-containing amino acids from feather meal or rumen-protected methionine. J. Dairy Sci., 84: 2515-2522. DOI: $10.3168 /$ jds.S0022-0302(01)74702-9

Rao, M.B., A.M. Tanksale, M.S. Ghatge and V.V. Deshpande, 1998. Molecular and biotechnological aspects of microbial proteases. Microb. Molecular Biol. Rev., 62: 597-635.

Reddy, M.R.K., R. Sathi, Y.R. Chouhan, B. Hameeda and R. Gopal, 2017. Effective feather degradation and keratinase production by Bacillus pumilus GRK for its application as bio-detergent additive. Bioresource Technol., 243: 254-263. DOI: 10.1016/j.biortech.2017.06.067

Riffel, A and A. Brandelli, 2006. Keratinolytic bacteria isolated from feather waste. Brazilian J. Microb., 37: 395-399. DOI: 10.1590/S1517-83822006000300036

Said, M.I., Y. Erwanto and E. Abustam, 2016a. Properties of edible film produced using combination of collagen extracts of bligon goatskin with glycerol. Am. J. Anim. Vet. Sci., 11: 151-159. DOI: 10.3844/ajavsp.2016.151.159

Said, M.I., F.N. Yuliati, M.Z. Mide, W. Pakiding and M. Sidik, 2016b. Chemical characteristics and macrostructure of hair concentrates of Bali Cattle produced from waste of skin crackers industry. Am. Eurasian J. Sustainable Agric., 10: 32-38.

Scholljegerdes, E.J., P.A. Ludden and B.W. Hess, 2005. Effect of restricted forage intake on ruminal disappearance of bromegrass hay and a blood meal, feather meal and fish meal supplement1. J. Anim. Sci., 83:2146-2150. DOI: 10.2527/2005.8392146x

Steel, R.G.D and J.H. Torrie, 1991. Principle and Procedure of Statistics. 2nd Edn., International Book Company, Tokyo.

Swaisgood, H.E and G.L. Catignani, 1991. Protein digestibility: In vitro methods of assessment. Adv. Food Nut. Res., 35: 185-236. DOI: $10.1016 / \mathrm{S} 1043-4526(08) 60065-0$

Tesfaye, T., B. Sithole, D. Ramjugernath and V. Chunilall, 2017. Valorisation of chicken feathers: Characterisation of chemical properties. Waste Manag., 68: 626-635.

DOI: 10.1016/j.wasman.2017.06.050 
Thiex, N. and C.R. Richardson, 2003. Challenges in measuring moisture content of feeds. J. Anim. Sci., 81: 3255-3266. DOI: $10.2527 / 2003.81123255 \mathrm{x}$

Van-Heugten, E. and T.A. Van-Kempen, 2002. Growth performance, carcass characteristics, nutrient digestibility and fecal odorous compounds in growing-finishing pigs fed diets containing hydrolyzed feather meal. J. Anim. Sci., 80: 171-178. DOI: $10.2527 / 2002.801171 \mathrm{x}$
Zerdani, I., M. Faid and A. Malki, 2004. Feather wastes digestion by new isolated strains bacillus $s p$. African J. Biotechnol., 3: 67-70.

DOI: $10.5897 / A J B 2004.000-2012$

Zheljazkov, V.D., 2005. Assessment of wool waste and hair waste as soil amendment and nutrient source. J. Environ. Quality Abs. - Waste Manage., 34: 2310-2317. DOI: $10.2134 /$ jeq2004.0332 